\title{
IMPROVING THE STUDENTS' WRITING ABILITY IN NARRATIVE TEXT THROUGH PRAISE-QUESTION-POLISH (PQP) TECHNIQUE
}

\author{
Hasnawati Latif \\ English Education Department, Faculty of Teacher Training and Education \\ Muhammadiyah University of Makassar \\ hasnawati.latif@unismuh.ac.id.
}

\begin{abstract}
The research aimed at improving the ability of the eighth year students of SMP Negeri 33 Makassar to write narrative text in terms of organization and language use by using Praise-Question-Polish (PQP) Technique. For the purpose, this research employed Classroom Action Research in which the researcher worked in planning, implementation of action, observation, and reflection on the data collected from the teaching and learning process and the students' writing products. The subjects of this research were 30 students of the first year students of SMP Negeri 33 Makassar in the academic year 2012/2013. The study was conducted in diagnostic test and two cycles, each cycle was carried out in four meetings. The findings indicated that using Praise-Question-Polish $(P Q P)$ Technique could improve the students' ability in writing narrative text. Before giving implementation the researcher gave the students diagnostic test and the mean score of diagnostic test was 40,2 (Poor). Then the researcher conducted the cycle 1 and the cycle 2, and the result showed that the students' scores in the cycle 1 and cycle 2 improved. In cycle 1, the mean score of students was 68,7(Fair), meanwhile the mean score of students in cycle 2 was 80,2 (Fairly good). The score of students' writing in term of organization in d-test was 50,4 (Poor) but after application of PQP ( Praise-QuestionPolish ) Technique the students' score became 67,8 (Fair) in cycle I, whereas in cycle 2 the students' score was 79 (Fairly Good). The score of students' writing in term of language use in d-test was 49,8 (Poor). In cycle I, it was improved became 69,4 (Fair) whereas in cycle 2 the students' score was 80,7 (Fairly Good). The percentage of students' participation in the first meeting of cycle I was $65,8 \%$ and it was improved became $82,5 \%$ in the last meeting of cycle 2.
\end{abstract}

Keywords: writing, orginization, language use, Praise - Question-Polish

\section{INTRODUCTION}

The language skills to be achieved are divided into two parts of language function, namely, oral and written English as a means of communication. In this case listening and speaking are oral language; reading and writing are written language. However for mastering them, the students must master tenses, because tenses are the important element in mastering English. (Murphy: 1992)

Unfortunately, one of those skills which the students usually find difficult is learning tenses. Based on the observation in SMPN 33 Makassar especially VIII Class, the students' writing skill poor. It is caused by many factors such as the teacher's way in teaching that they sometimes use the same teaching techniques 
which make the students are bored. The other factor is they do not know how to start it because they do not have enough ideas to write and could not generate their ideas, or probably they don't understand what they have to do. Finally the students become anxious when they attempt to write and get panicky at the sight of the blank page even say that they have a writing phobia.

To solve the problems above, the teacher has to find out interesting technique and more creative to motivate students in writing process. Therefore, one simplest way of making writing more creative and meaningful to the students is to have the students to write something about their feeling, motivation, their weakness, their strength, and all about their self.

\section{CONCEPT OF WRITING}

\section{Definition of Writing}

Writing is transpiring data or feeling to another as the reader. In another word, it is a communication process by undirected speech or reported speech. In addition, D' Angelo in Indrayani (2007), states that writing is a form of thinking for a particular audience, and for a particular occasion. According to this concept that one of the most important tasks as a writer is to master the principles of writing and thinking that will help to achieve his goal. The most important of these principles are those of invention arrangement, and style invention is the process of discovering ideas for speaking or writing arrangement.

Widdowson (1983), defines that writing is a communicative activity and so is carried out in accordance with certain general principles in which underline the use of language in communication.

Ron White in Melay (1980 : 7-8), states that sentence level reinforcement exercises' they clearly have their value in language learning, but successful writing depends on more than the ability to produce clear and correct sentences.

\section{The Concept of Praise-Question-Polish (PQP) Technique}

\section{Definition of Praise-Question-Polish (PQP) Technique}

This revising strategy (Neubert \& McNelis, 1986) is appropriate for a second round of revision and editing (a third round would involve conferring with the 
teacher) during which students work with one another. The prompt sheet indicates that a peer editor is to first read the author's paper and mark those parts of the paper that are imaginative, unusual, interesting, and confusing. Then, the peer editor praises the author for the positive aspects and questions the author about the confusing parts. The peer makes suggestions for how the paper can be improved and gives back the original, marked copy to the author. Finally, the author addresses the confusing parts marked on the paper and, if desired, makes changes suggested by the peer editor. Whenever a student elects to not make a requested or suggested modification, the student should be expected to adequately justify that decision (this encourages ownership and responsibility).

Praise-Question-Polish (PQP) is a peer response strategy that fosters quality comments and constructive feedback. It helps you compliment one another's work, question areas where revision may be needed, and make specific suggestion to improve expression and the quality of text. (Mrs. Leite). Praise-Question-Polish $(\mathrm{PQP})$ is a revision strategy teach students to use when participating in peer revision groups. Modified this strategy from a lesson.

\section{Teaching Students How to Respond to Writing Using PQP'}

PQP stands for praise, question, and polish. It is revision strategy I teach my students to use when participating in peer-revision groups. I modified this strategy from a lesson Ben Nelms, dean of the University of Florida's College of education and former editor of the English Journal, taught during a graduate class. It was originally taught as a way to teach new teachers hw respond to student writing. (Nelms : 1990)

1. Praise

Students should always begin any revision session by pointing out the good qualities of another student's paper. It is extremely important that you model this strategy with students; otherwise, you will get comments like, "I liked it" or "It was good." Show students how to isolate specific aspects of a piece of writing such as, "I love the way you started your story with a flashback..." or "The description of your father was wonderful. I could see how mad he was at you."

2. Question 
Teach students how to ask what Barry Lane calls "focusing questions" or "W-questions." W-questions like Who, What, Where, When and Why pinpoint specific areas of revision. If students ask questions like "Was your dad mad?" the writer can answer, "Yes" and not do any revision. If a Wquestion is asked, "Why was your dad mad?" the writer must go back and include more description to answer that question.

3. Polish

This is perhaps the hardest of the three because most students don't know the difference between polishing or revising a piece of writing and editing it. Most students want to provide comments like, "Write neater" or "Check your spelling." I tell my students that editing a paper makes it easier to read, but it does not necessarily make the writing better. Polish comments are suggestions one student gives another. The writer does not have to follow that suggestion if he she does not feel it is needed. Good polish suggestions are suggestions such as adding more details, adding another character, developing the plot in more detail, using more figurative language, adding or deleting dialogue, removing cliques or the use of slang, reducing over used words, i.e. the "and then..." papers so many students write.

\section{The Procedure of Praise-Question-Polish (PQP)}

There are some procedure of Praise-Question-Polish (PQP) by Lyons (1981:42-43):

1. Read any current magazine article or fiction piece that might be of interest to students, but leave out important details.

2. After reading the piece, engage the students in discussion on the following three questions:

a. What did you really enjoy or think was especially interesting about this piece?

b. Was there anything you didn't understand or parts that seemed unclear? Were any implied questions left unanswered? 
c. If you were the editor preparing this piece for publication, what advice would you have for the writer that would make this piece of greater interest for the reader?

3. Explain that the conversation that the class just engaged in is a process called PQP: Praise, Question, Polish. This process is a way to critically evaluate material that you have read or heard and is one that adults in real life situations engage in all the time: people discuss news articles and broadcasts, books, and speeches given by politicians in just this way. Remind students that they will one day be adults who should be able to critically evaluate information they hear and read, if for no other reason so they can vote responsibly on political candidates and issues

4. Explain further that this process is also a COLLABORATIVE process and will provide a framework for each student to get helpful feedback from his or her peers as he/she revises for precision and clarity. Remind students that they typically will write for an audience of educated adults, and that in the adult world of work, people typically get feedback from others on letters, reports, and contracts to insure the communication is clear and precise.

5. Ask: Are here are other situations they may be in as adults where they would have to critically evaluate issues? Allow students to brainstorm when these skills would be helpful. (school issues, work-related issues, legal issues, financial issues, etc.)

6. Explain that they will be using this process throughout the year to not only hone their own critical thinking skills but to help each other sharpen their communicate skills, both oral and written.

7. Divide the class into groups of 3-4 students. Instruct them in this process by emphasizing several important aspects:

a. This is an oral process. As such each person will read aloud his/her paper to the group and the group must listen carefully (and make personal notes if necessary) in order to be able to give feedback to the reader.

b. A second paper will be read only AFTER the entire group has thoroughly discussed the first paper. 
c. After a paper has been read aloud, each person in the group should share what he/she thought was especially interesting or something they liked. (This may include descriptions, humorous anecdotes, or the skilled way the writer built suspense.)

d. Next, each person in the group asks at least one question to clarify issues that the writer may not have clarified. (Remind students to consider implied questions that may have been unanswered.)

e. Finally, each person in the group gives the writer ONE suggestion for improving the piece.

f. Although a student may PASS in each round of the process, encourage students to find something to comment on (assuming that none of us are so skilled that we can't benefit from the critical evaluation of our writing).

g. The writer/reader should note suggestions and comments on his/her own paper throughout the process so that appropriate changes can be made in the next draft of the piece.

8. Initially, this lesson may take two days (one to explain the process and one for students to engage in it). After this initial introduction, however, students should be able to move into small groups and complete this process when appropriate without much explanation beyond, "It's time to move into PQP groups.”

\section{METHODOLOGY}

In this research design, the researcher used class action research (CAR) with two cycles and each cycle consists of four meetings. The method employed by the researcher through 4 steps namely planning, action, observation, and reflection. Remembering that variable was one of the very important elements of research, the research used two kinds include of variable. It variable can be divided into two variables. Those were dependent variable and independent variable that is the variable that influence the other variable Research subject in this classroom action research was the VIII grade students of SMPN 33 MAKASSAR in 2012 - 2013 academic years. 
The instrument in this research were observation and writing test. The test was given to the students as diagnostic test for getting focus of the problem before the cycle of CAR is applied, test in each cycle, and test after applying the action as evaluation test. Kind of test that was given in writing narrative text. The researcher used observation sheet out the students' participant in teaching learning process through whole language approach. It was done in every cycle. It was summed at the end of cycle one and two. The researcher gave test to students to find out their improvement of students in writing narrative text by using PQP (Praise-Question-Polish). The researcher gave test to students. There were two components that concerns of the researcher in this research to measure.

\section{FINDINGS AND DISCUSSIONS}

\section{A. Findings}

1. The Mean Score and Improvements of the Students' writing viewed from its Organization

\section{a. The Mean Score and Improvement}

The mean score and improvements of the students' writing viewed from its organization through Praise-Question-Polish (PQP) that can be seen clearly based on the following table:

Table 2.1. The Mean Score and Improvements of the Students' Writing viewed from its organization

\begin{tabular}{|c|c|c|c|c|c|c|}
\hline \multirow{2}{*}{ Indicator } & \multicolumn{3}{|c|}{ Mean Scores (\%) } & \multicolumn{3}{c|}{ Improvement (\%) } \\
\cline { 2 - 7 } & D-Test & Cycle I & $\begin{array}{c}\text { Cycle } \\
\text { II }\end{array}$ & $\begin{array}{c}\text { DT-C I } \\
(\%)\end{array}$ & $\begin{array}{c}\text { C I-C II } \\
(\%)\end{array}$ & $\begin{array}{c}\text { DT-CII } \\
(\%)\end{array}$ \\
\hline Organization & 50,4 & 67,8 & 79,0 & $34,52 \%$ & $16,51 \%$ & $56,74 \%$ \\
\hline
\end{tabular}

The data in the table above shows the students' writing ability in organization as the result of calculating of the diagnostic test and students' test at the students' writing ability through Praise-Question-Polish (PQP), where the students' score in diagnostic test is different from the students' test in cycle I. The mean score in diagnostic test is 50,4 in cycle $\mathrm{I}$ is 67,8 , and in cycle II is 79,0 The assessment of cycle II is greater than cycle I and diagnostic test $(79,0>67,8>$ 
$50,4)$ and classified as good. And then, improvement from D - test to cycle II is greater than D - Test to cycle I $(56,74 \%>34,52 \%)$.

The mean score and improvements of the students' writing viewed from its generic structure with indicators can be also seen in the two charts below:

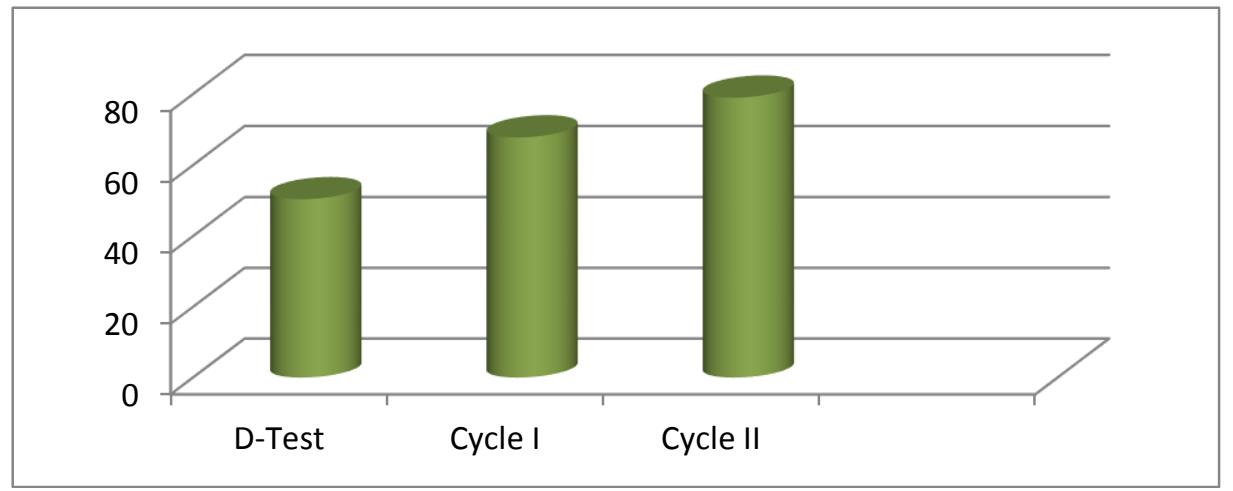

Chart 2.1. Chart the Mean Scores of the Students' Writing viewed from its Organization

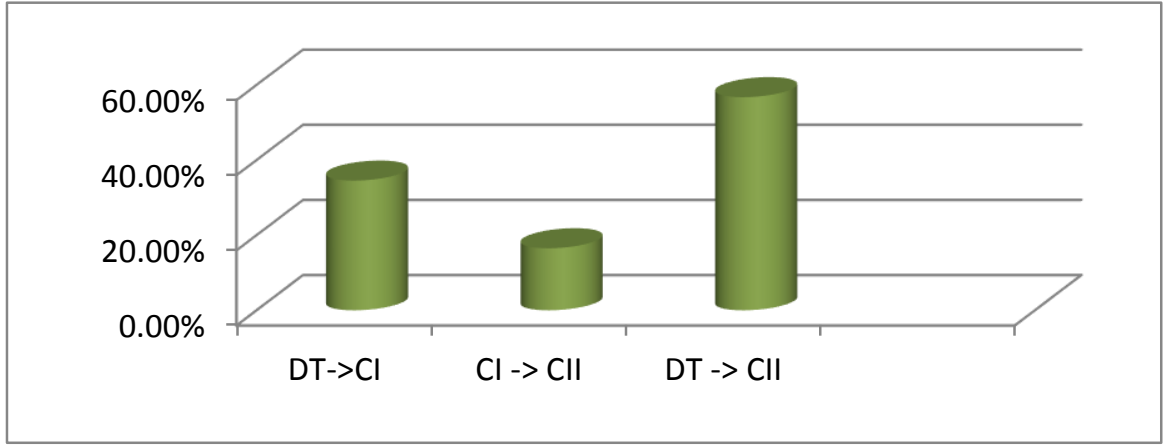

Chart 2.2. Chart the improvement of the Students' Writing viewed from its Organization

The first chart above indicates that the mean score of the students' writing viewed from its organization are 50,4 in D-Test while in cycle I the mean score is 67,8 and 79,0 in cycle II. The second chart indicates the comparison of the students' writing viewed from its organization improvement from D-test to cycle I is $34,52 \%$, cycle I to Cycle II is $16,51 \%$, and D-test to Cycle II is $56,74 \%$. From these findings above, it can be indicated that there is a significant improvement in applying Praise-Question-Polish (PQP) in improving the students' English writing in organization. 


\section{The Mean Score and Improvement of the Students' writing viewed from its language use \\ a. The Mean Score and Improvement}

The improvement of the students' writing viewed from its language use through Praise-Question-Polish (PQP) that can be seen clearly based on the following table:

\begin{tabular}{|c|c|c|c|c|c|c|}
\hline \multirow{2}{*}{ Indicator } & \multicolumn{3}{|c|}{ Scores (\%) } & \multicolumn{3}{c|}{ Improvement (\%) } \\
\cline { 2 - 7 } & D-Test & Cycle I & Cycle II & $\begin{array}{c}\text { DT-C I } \\
(\%)\end{array}$ & $\begin{array}{c}\text { C I-C II } \\
(\%)\end{array}$ & $\begin{array}{c}\text { DT-CII } \\
(\%)\end{array}$ \\
\hline Language Use & 49,8 & 69,4 & 80,7 & $39,35 \%$ & $16,28 \%$ & $62,04 \%$ \\
\hline
\end{tabular}

Table 2.3. The Mean Score and Improvement of the Students' Writing viewed from its Language Use

The data in the table above shows the students' writing viewed from its language use the result of calculating of the diagnostic test and students' test at the students' writing ability through Praise-Question-Polish (PQP), where the students' score in diagnostic test is different from the students' test in cycle I and cycle II. The mean score in diagnostic test is 49,8 , the students' test in cycle I is 69,4 and cycle II is 80,7 . The achievement of cycle II is greater than cycle I and diagnostic test $(80,7 \%>69,4>49,8 \%)$ and classified as good. And then, improvement from D - test to cycle II is greater than D - Test to cycle I ( $62,04 \%$ $>39,35 \%$ ).

The mean score and improvements of the students' writing viewed from its language use with indicators can be also seen in the two charts below:

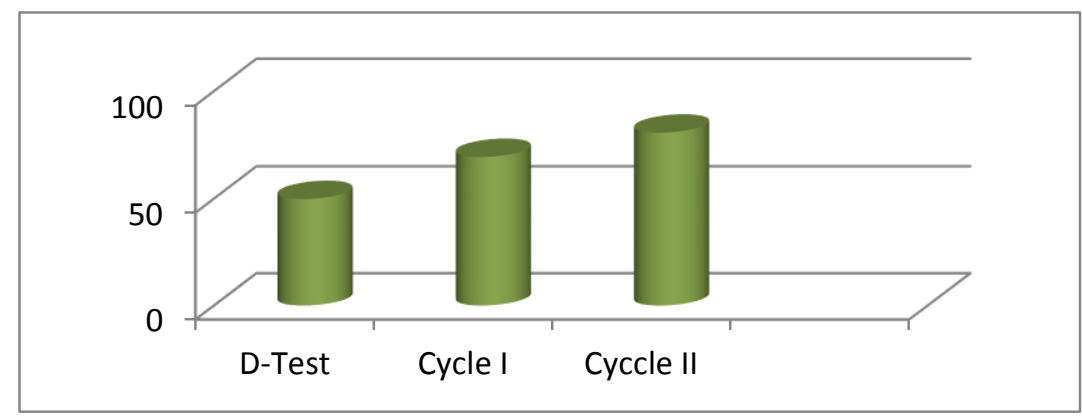

Chart 2.4. Chart the Mean Scores of the Students' Writing viewed from its Language Use 


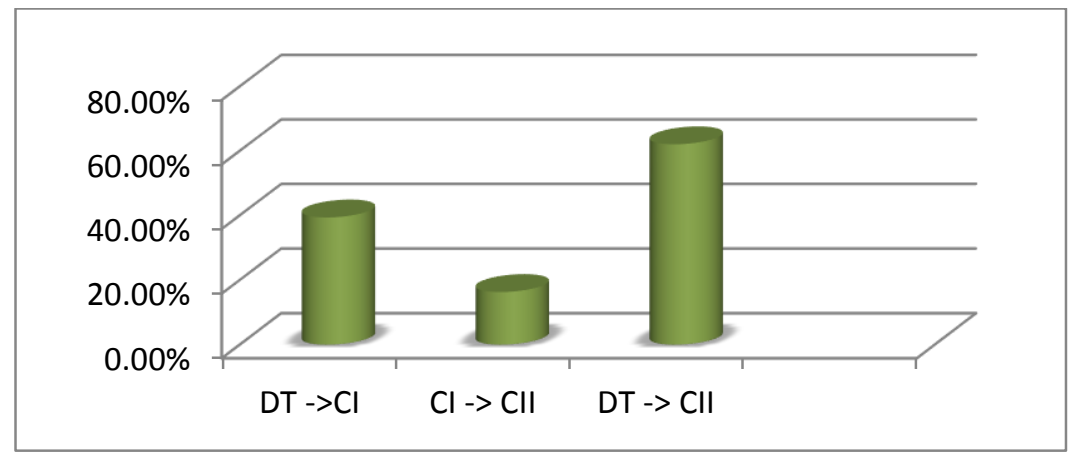

Chart 2.5. Chart the improvement of the Students' Writing viewed from its Language Use

The first chart above indicates that the mean score of the students' writing viewed from its language use are 49,8 in D-Test while in cycle I the mean score is 69,4 and 80,7 in cycle II. The second chart indicates the comparison of the students' writing language use improvement from D-test to cycle I is 39,35\%, cycle I to Cycle II is 16,28\%, and D-test to Cycle II is 62,04\%. From these findings above, it can be indicated that there is a significant improvement in applying the Praise-Question-Polish (PQP) in improving the students' English writing in language use.

\section{The Improvement of the Students' Writing Ability}

\section{a. The Improvement}

The improvement of the students' writing ability in term of organization and language use through Praise-Question-Polish (PQP) is good. It is indicated by the mean score of cycle 1 and cycle II tests which are shown clearly in the following table:

\begin{tabular}{|c|c|c|c|c|c|c|}
\hline \multirow{2}{*}{ Variables } & \multicolumn{3}{|c|}{ Scores (\%) } & \multicolumn{3}{c|}{ Improvement (\%) } \\
\cline { 2 - 7 } & D-Test & Cycle I & Cycle II & $\begin{array}{c}\text { DT-C I } \\
(\%)\end{array}$ & $\begin{array}{c}\text { C I-C II } \\
(\%)\end{array}$ & $\begin{array}{c}\text { DT-CII } \\
(\%)\end{array}$ \\
\hline Organization & 50,4 & 67,8 & 79,0 & $34,52 \%$ & $16,51 \%$ & $56,74 \%$ \\
\hline Language Use & 49,8 & 69,4 & 80,7 & $39,35 \%$ & $16,28 \%$ & $62,04 \%$ \\
\hline$\sum \mathrm{x}$ & 100,2 & 137,2 & 159,7 & $73,87 \%$ & $32,79 \%$ & $118,78 \%$ \\
\hline $\bar{X}$ & 50,1 & 68,6 & 79,8 & $36,93 \%$ & $16,39 \%$ & $59,39 \%$ \\
\hline
\end{tabular}

Table 2.5. The Students' Improvement in Writing ability

The table above shows the mean score of students' achievement writing ability in narrative text both of organization and language use. Based on the table, 
it indicated that the improvement of the students' writing ability by PraiseQuestion-Polish (PQP) was successful. The students' mean score in d-test was 50,1 classified into very poor score, the students' mean score in cycle I was 68,6 classified into fairly good score and the students' mean score in cycle II was 79,8 classified into Good score. So, the improvement of the students' writing ability between d-test to cycle I was, then, the improvement between d-test to cycle I was 36,93 , the improvement between cycle I to cycle II was $16,39 \%$, and the improvement between d-test to cycle II was 59,39\%. Based on the percentages above there are significant improvement of students' writing ability by PraiseQuestion-Polish (PQP). To see clearly the improvement of the students' writing skill, the following chart is presented.

To see clearly the mean score and the improvements of the students' writing ability, two charts are presented as follows:

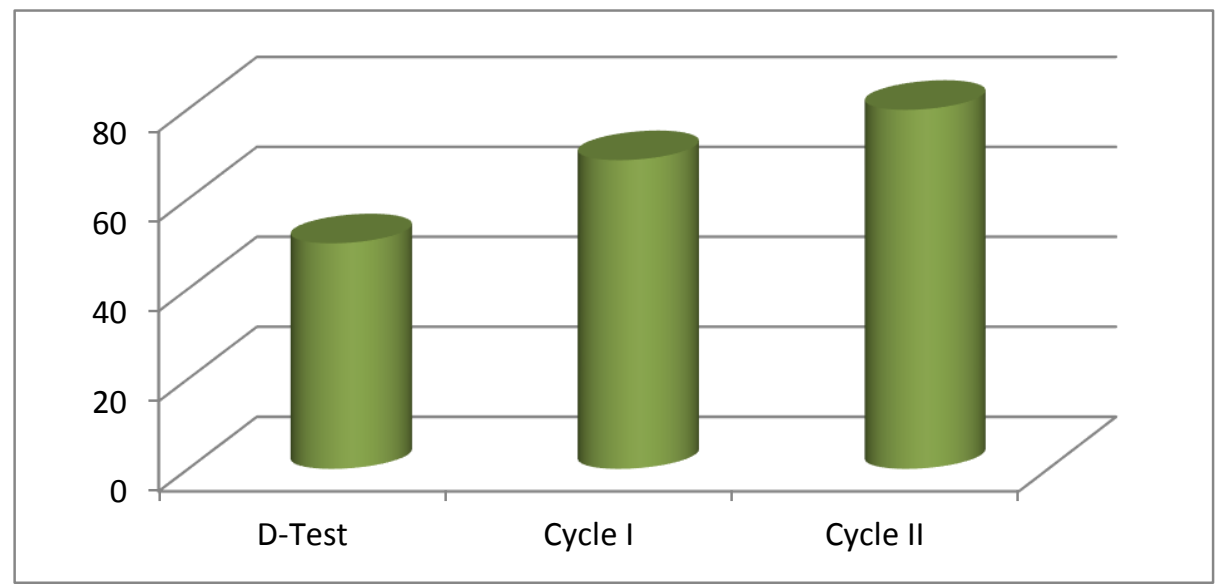

Chart 2.7. Charts the mean scores of the Students' writing ability

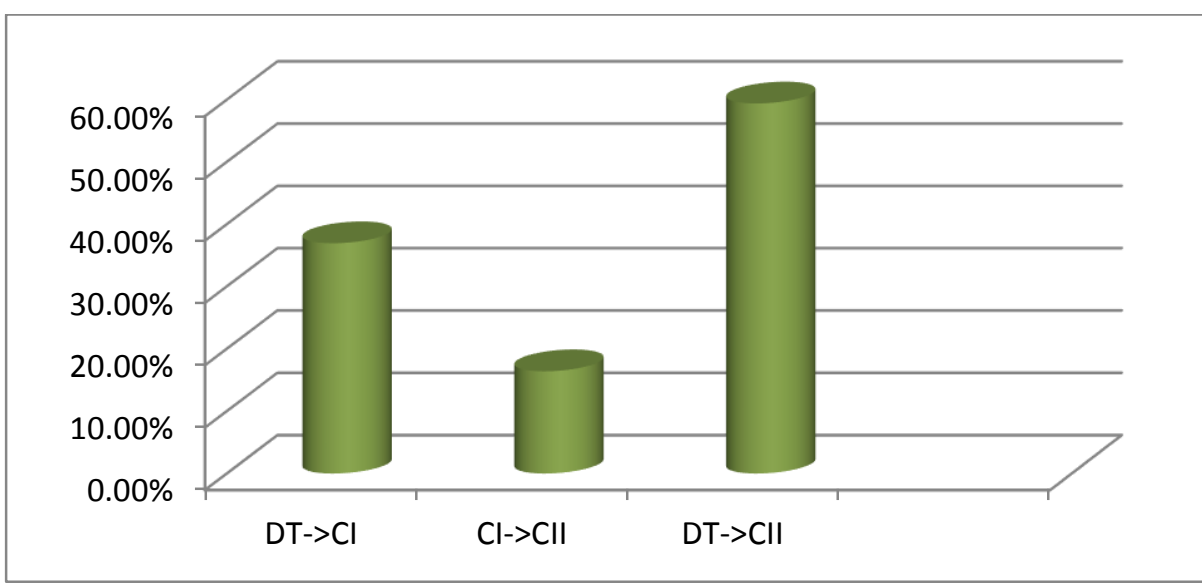

Chart 2.8. Charts the improvement of the Students' writing Ability 
The first chart above show that the mean score of the students' writing ability in D-test is 50,1. It is categorized as a poor category. After implementing an action in cycle I, the students' writing ability becomes 68,6. It is categorized as a fairly good category, but in cycle II the students' mean score becomes 79,8 and it is categorized as a good category.

The second chart shows that the students' writing ability improvement from D-test to cycle I is $36,93 \%$, from cycle I to cycle II is $16,39 \%$, and from Dtest to cycle II is $59,39 \%$. It indicates that there is a significant improvement of the students' writing ability through Praise-Question-Polish (PQP). In other words, it can be indicated that the students' writing ability can improve through Praise-Question-Polish (PQP).

\section{The Result of the Students' Activeness in Teaching and Learning Process}

The result of observation of the students' activeness in teaching and learning process through Praise-Question-Polish (PQP) in improving the students' ability in writing narrative text achievement at the Eighth Grade Students of SMP Negeri 33 Makassar in class VIII account which is conducted in 2 cycles during 8 meetings is taken by the observer through observation sheet.

The following table and chart show the observation result of the students activeness in learning writing of cycle I and cycle II.

\begin{tabular}{|c|c|c|c|c|c|}
\hline \multirow{2}{*}{ Cycle } & \multicolumn{4}{|c|}{ Meetings } & \multirow{2}{*}{$\begin{array}{c}\text { Average } \\
\text { Score }\end{array}$} \\
\cline { 2 - 6 } & I & II & III & IV & \\
\hline I & $65,8 \%$ & $66,6 \%$ & $70,8 \%$ & $77,5 \%$ & $70,2 \%$ \\
\hline II & $74,1 \%$ & $75,8 \%$ & $77,5 \%$ & $82,5 \%$ & $77,5 \%$ \\
\hline
\end{tabular}

Table 2.7 : The Percentage of Students' Activeness

Based on the table above, the students' participation was improved. At the first meeting in the cycle I the students' activeness was 70,2\% whereas in the last meeting at the cycle II the students' activeness was $77,5 \%$. 


\section{CONCLUSIONS}

Praise-Question-Polish (PQP) was one of a good strategy in writing narrative text. The data above indicated that this strategy had succeeded to improve the students' achievement in writing narrative text at SMP Negeri 33 Makassar.

1. The students' score in writing result in d-test was 50,1, in cycle I the students' score was improved 68,6 and in the cycle II the students' score became 79,8. the students improvement from d-test to cycle I was $36,93 \%$, cycle I to cycle II was $16,39 \%$, and d-test to cycle II was $59,39 \%$.

2. The score of students' writing in organization in d-test was 50,4. in cycle I it was improved become 67,8, where as in cycle II the students' score was 79,0. the students improvement from d-test to cycle I was $34,52 \%$, cycle I to cycle II was $16,51 \%$, and d-test to cycle II was $56,74 \%$.

3. The score of students' writing in language use in d-test was 49,8. in cycle I it was improved become 69,4, whereas in cycle II the students' score was 80,7. the students improvement from d-test to cycle I was $39,35 \%$, cycle I to cycle II was $16,28 \%$, and d-test to cycle II was $62,04 \%$.

\section{REFERENCES}

Adelstein, M,M.E. \& J.G. Pival. 1980. The Writing Commitment. New York. Doc. Retrieved from (http://edutechwiki.unige.ch/en/Writing). Accessed on June $2^{\text {nd }}, 2012$.

Breveton, 1982. A Plan for Writing Skills. New York: CBS College publishing.

Byrne, Donn. 1988. Teaching Writing Skill. England. Longman.

Charles, Martin Et Al. 1985. Exploring American English. New York. Macmillan Publishing Compony.

Depdikbud. 2004. GBPP Bahasa Inggris. Jakarta: Dikdasmen. (http://www.Depdikbud.com/kurikulum/education).

Fatmawaty, 2008. Increasing the Students' Writing Proficiency through ThinkTalk-Write Method. Makassar. Thesis Unismuh.

Gay, L. R. 1981. Education Research. New York: Prentice Hill.

Harmer, Jeremy. 1987. Teaching and Learning Grammar. London: Longman. 
Harwanto. 2005. Penelitian Tindakan Kelas. Jakarta: Bumi Aksara.

Heaton, J. B. 1975. Writing English Language Test. London and New York: Longman.

Hoirston, Anne Covel. 1986. Teaching English Form, Vol. XXIX: 10- 11. Hongkong: City Polytechnic of Hongkong.

Indrayani, Mastira. (2007) Improving Students' Ability to write descriptive paragraph by using photographs. Thesis S1, UNM Makassar.

Keraf (1989; 136). Argumentasi dan Narasi. Jakarta; Gramedia

Melay, Alan. 1992. Resource Books for Teachers. Oxford University.

Murphy, Raimond. 1992. Grammar Practice for TOEFL U.S.A. New Jersey: Arcoart Brace Jovanich Publisher

Neubert, G. A. \& McNelis, S.J. (1986). Improving Writing in the Disciplines. Educational Leadership, 43 (7), 54-58

Nelms, Ben. 1990. Former Editor of the English Journal. (http://www.angelfire.com/fl4/macmucci/PQP.html) University of Florida College of Education. Accessed on Saturday June $2^{\text {nd, }} 2012$

Oshima, Alice and Ann Hogue. 1997. Introduction to Academic Writing. London and New York: Longman Group UK Limited.

Rosfita, Wa Ode. 2011. The Application on Total Physical Response in Teaching English Vocabulary. Thesis FKIP: Dayanu Ikhsanuddin University of Baubau.

Sudjana. 1990. Metode statistika. Bandung: Pt. Gramedia

Syaparuddin, Talib. 2010. Improving the students' writing narrative paragraph through guided question technique. Thesis. FKIP UMM Makassar.

Temple, Charles, A. Nathan, Ruth Burris, Nancy Temple, Frances. 1982. The beginning of writing (second edition). Copyright by Allyn and Bacon, Inc. United States of America.

Trinata, Ita, Y. (2010). Developing Narrative performance of the First Grade at SMAN 1 Bau-Bau Based on Their Experience. Thesis S2. UNM

Wahid, Abdul. 2011. The Effectiveness of Animation Movie in Improving the Students' Writing Skill of Narrative Text. Thesis FKIP. UMM Makassar. 
Widdowson 1983. Learning to write: first language / second language. London. Pdf.(http://www.education.com/reference/article/constructivism) Accessed on November $2^{\text {nd }}, 2011$

Yuharniaty. 2002. The Students' Ability to Write English through Tourism Brochure. Thesis. FKIP UMM Makassar. 